\title{
Characteristics and source tracing of organic carbon in intertidal sediments of wetland in Yangtze Estuary, China
}

\section{Haiyan Yu}

Tongji University College of Environmental Science and Engineering

\section{Weiwei Li}

Tongji University College of Environmental Science and Engineering

Changxu Han

Tongji University College of Environmental Science and Engineering

\section{Han Fang}

Tongji University College of Environmental Science and Engineering

\section{Xingquan Shu}

Tongji University College of Environmental Science and Engineering

\section{Yongfeng Liu}

Tongji University College of Environmental Science and Engineering

\section{Yuwei Pan}

Nanjing Forestry University

\section{Limin Ma ( $\nabla$ Imma@tongji.edu.cn )}

Tongji University College of Environmental Science and Engineering https://orcid.org/0000-0002-38192111

\section{Research}

Keywords: Estuary, Sediment, Organic carbon, Biomass, Carbon stable isotope

Posted Date: January 7th, 2020

DOI: https://doi.org/10.21203/rs.2.20180/v1

License: (c) (1) This work is licensed under a Creative Commons Attribution 4.0 International License. Read Full License 


\title{
Characteristics and source tracing of organic carbon in intertidal
} sediments of wetland in Yangtze Estuary, China

Haiyan $\mathrm{Yu}^{\mathrm{a}}$, Weiwei $\mathrm{Li}^{\mathrm{a}}$, Changxu Han ${ }^{\mathrm{a}}$, Han Fang ${ }^{\mathrm{a}}$, Xingquan Shu $\mathrm{S}^{\mathrm{a}}$, Yongfeng Liu ${ }^{\mathrm{a}}$,

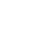

\author{
Yuwei Pan ${ }^{\mathrm{b}}$, Limin $\mathrm{Ma}^{\mathrm{acd} *}$
}

${ }^{a}$ College of Environmental Science and Engineering, Tongji University, Shanghai 200092, China

${ }^{b}$ College of Biology and the Environment, Nanjing Forestry University, Nanjing 210037, China

c Key Laboratory of Yangtze River Water Environment, Ministry of Education, Shanghai 200092, China

${ }^{\mathrm{d}}$ Shanghai Institute of Pollution Control and Ecological Security, Shanghai 200092, China

* Corresponding author at: College of Environmental Science and Engineering,

Tongji University, Shanghai 200092, China.

E-mail address: 1mma@tongji.edu.cn.

\footnotetext{
* Corresponding author at: College of Environmental Science and Engineering, Tongji

University, Shanghai 200092, China

E-mail address:1mma@tongji.edu.cn
} 


\section{Abstract}

Background: Wetland ecosystem is characterized by water-land interaction and plays an important role in regional energy and material circulation. In the context of global climate change, the study of wetland carbon storage and carbon cycle has become a focus of academic attention. The characteristics of organic carbon in sediments and its source is a key problem in the study of carbon cycle in wetlands.

Results: In this study, the characteristics of total organic carbon (TOC), total nitrogen (TN) accumulation, and stable carbon isotope $\left(\delta^{13} \mathrm{C}\right)$ in the vegetation and soil were investigated for the three dominant salt marsh vegetation Phragmites australis (PA), Spartina alterniflora (SA), Scirpus mariqueter (SM) of the coastal wetlands of Chongming Dongtan in the Yangtze River Estuary. The results showed that the mean value of TOC and TN concentrations in the surface sediments of wetland were $1.39 \pm$ $0.34 \%$ and $0.091 \pm 0.024 \%$, respectively. The carbon stable isotope $\left(\delta^{13} \mathrm{C}\right)$ mean value of sediment was $-24.17 \pm 1.51 \%$. The TOC of the sediment in the three saltmarsh plant communities was in the order of SA $(1.76 \pm 0.38 \%)>\mathrm{PA}(1.45 \pm 0.37 \%)>\mathrm{SM}(0.96 \pm$ $0.44 \%$ ). The simulation results of the three end-member mixing equations showed that the organic carbon in sediments was mainly derived from suspended particles $(42.44 \pm$ $20.89 \%)$ and vegetation $(34.50 \pm 25.23 \%)$. The contribution rate of microalgae is lower $(23.06 \pm 4.62 \%)$.

Conclusion: The organic carbon in sediments of wetland in Yangtze Estuary are the result of mixed input of terrestrial organic carbon and marine organic carbon. Organic carbon in sediments was mainly derived from suspended particles and vegetations. The 
results provide preliminary knowledge of the distribution and sources of sedimentary organic carbon for better understanding the sediment transport and deposition in this region.

Keywords : Yangtze Estuary, Sediment, Organic carbon, Biomass, Carbon stable isotope

\section{Background}

Estuary wetlands, as the interaction zone between terrestrial ecosystems and marine ecosystems, are the ecosystems with the highest ecological service value per unit area, and have various economic functions, ecological functions, and scientific values [1-3]. Under the action of physical, chemical and biological processes, a large amount of organic matter from the land and sea sources are accumulated in the ecosystem $[2,4]$. Salt marsh is an important natural carbon sink, and its global average carbon fixation efficiency of surface sediments is as high as $244.7 \mathrm{~g} \mathrm{C} / \mathrm{m}^{2} / \mathrm{a}$, which is helpful to alleviate global warming trends [5-10]. In addition, coastal wetland vegetation has high primary productivity, and its productivity per unit area can reach 3 times than that of tropical forests, which has greatly contributed to the increase of soil carbon storage $[2,11]$. It has been reported that coastal wetlands can become highly efficient carbon sinks under the combined effects of physical, chemical, and biological processes [12]. In the context of climate change, the accumulation of carbon in coastal wetland ecosystems and their sources have been received more and more attention [13]. 
There are many sources of organic carbon stored in sediments such as land sources and sea sources [14]. And the biogeochemical behaviors of different sources organic carbon vary greatly [15]. Therefore, it is significant to identify the sources of organic carbon in sediments for further understanding the carbon sequestration mechanism in wetlands. Yangtze River is the third largest river in the world, and its estuary area is one of the most concerned areas for the study of land-sea interaction. Yangtze estuary wetland is an important international wetland, an important habitat for international migratory birds, and a key area for the biodiversity of China's coastal wetlands [3]. The river carries a large amount of organic matter into the estuary area, and after a series of physical actions and biogeochemical processes such as adsorption, sedimentation, and resuspension, the river eventually settles in the estuary and inshore waters [16]. Yangtze river wetland is muddy with heavy silt, strong interaction between land and sea, and the sedimentation rate is extremely high [10]. The vegetation types of wetlands are complex and diverse. Due to the introduction and rapid diffusion of $\mathrm{C} 4$ plants, the coverage rate of native C3 plants (Phragmites australis (PA), Scirpus mariqueter (SM) ) on the beach has decreased sharply [17], which makes the spatial distribution and source composition of organic carbon content in sediments particularly complicated. At the same time, under the common influence of natural changes and human activities, the sediments of the Yangtze River into the sea showed a decreasing trend, while the nutrient flux continued to rise [18]. Wetland dynamic changes and ecological service functions always are the focus of scholars. In the past years, many scholars have made a great deal of researches on the changes of erosion and deposition of wetland, 
environmental changes, function zoning, and the impact of alien species Spartina alterniflora (SA) on the local ecosystem [19-21]. Mei et al. [22] and Yan et al. [23] have reported that the change of biomass during the growth of wetland plants will affect the spatiotemporal distribution of carbon $(\mathrm{C})$ in wetland soil, and the increase of soil carbon storage has a significant linear relationship with plant biomass [23]. In addition, some studies have reported that due to tidal action, the upstream sediment will accumulate in the coastal wetland, which will also affect the $\mathrm{C}$ and nitrogen $(\mathrm{N})$ contents of the wetland soil [24, 25]. At present, the use of tracers to explore the response of sediments in the estuary to changes in watersheds has become increasingly mature, and carbon is an important indicator of organic carbon [26, 27]. However, there is less information on the distribution characteristics and sources of organic carbon in estuarine wetland sediments using isotopic techniques. Therefore, the purpose of this study was to investigate total organic carbon (TOC), total nitrogen $(\mathrm{TN})$, carbon stable isotope $\left({ }^{13} \mathrm{C}\right)$ and carbon/nitrogen ratio $(\mathrm{C} / \mathrm{N})$ in the surface sediments of estuarine wetlands, and to explore the distribution characteristics, source composition and influencing factors of organic carbon in the sediments in the study area, so as to provide references for the formulation of carbon sequestration measures in the wetland of the Yangtze river estuary.

\section{Materials and methods}

\section{Study area}

The study area $\left(31^{\circ} 48^{\prime} \mathrm{N} \sim 31^{\circ} 49^{\prime} \mathrm{N}, 121^{\circ} 96^{\prime} \mathrm{E} \sim 121^{\circ} 98^{\prime} \mathrm{E}\right)$ is located Chongming Dongtan salt marsh of the Yangtze Estuary (Fig. 1). Due to at the estuary of the Yangtze 
river, under the influence of a large amount of sediment, continuously silting, the average annual silting increase of $80 \sim 110 \mathrm{~m}$ [10]. The study area is one of the largest and most complete tidal flat wetlands in the estuarine area, which is subject to the deposition of land source materials carried by the runoff of the Yangtze river. The terrain is gentle, with a slope of $0.02 \% \sim 0.05 \%$ and a soil salinity of $0.3 \% \sim 0.6 \%[2,3]$. The climate belongs to the north sub-tropical marine climate, with the average annual temperature between 15 and $16^{\circ} \mathrm{C}$, and abundant precipitation, mostly concentrated in

117 June and October [28]. The main salt-marsh vegetation in the study area was Phragmites australis (PA), Spartina alterniflora (SA), Scirpus mariqueter (SM) [29].

Since its large-scale introduction in 2001 and 2003, it has gradually encroached on the distribution areas of SA, PA, SM, and blackcuraria in Dongtan, Chongming, becoming one of the dominant species of salt marsh vegetation [30].

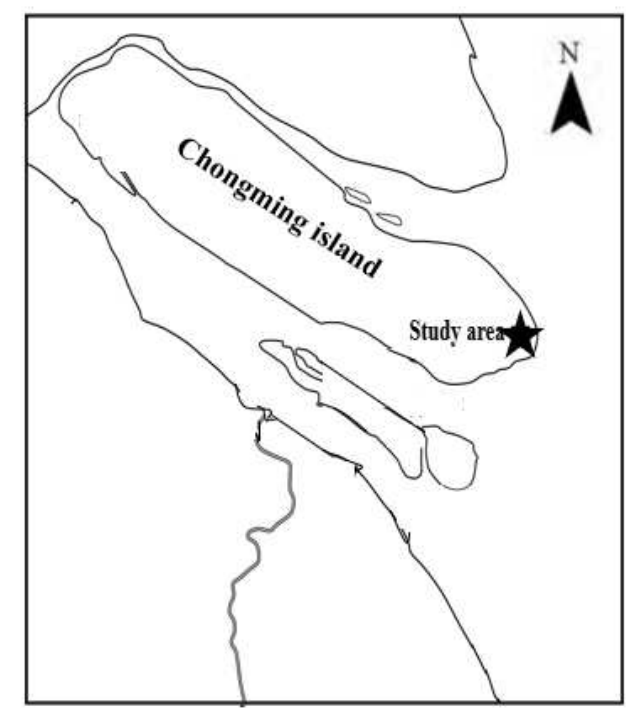

Fig.1. The map of the study area. 
A total of 15 sampling sites were obtained by dividing the sediment column samples.

These samples cover the three typical types of vegetation, including SA, PA, and SM zones. Three $50 \mathrm{~cm} \times 50 \mathrm{~cm}$ plant quadrats were randomly set at each sample sites, and the spacing between each quadrats was $>5 \mathrm{~m}$, and the living parts of plants (excluding dead plants) in the sample square were cut evenly. The plant samples (leaf, stems, and roots) were washed with tap water multiple times, and then washed with Mill-Q water 3 times. The plant tissue was cut into kraft paper bags and placed in an oven, and then killed at $105{ }^{\circ} \mathrm{C}$ for $2 \mathrm{~h}$, and then dried at $70{ }^{\circ} \mathrm{C}$ to a constant amount to determine the dry matter mass, and then calculate the aboveground and underground biomass of the plant per unit area. For more details of the specific methods, see "Physical and Chemical Analysis of Soils" [31]. The sediment samples were naturally air-dried and ground, and then subjected to 1.00 and $0.25 \mathrm{~mm}$ earth sieve. The samples were placed in polyethylene bags to preserve the sediment TOC for the determination of the samples. TOC was determined by potassium dichromate external heating method. TN was determined by kjeldahl method [31]. The $\mathrm{C} / \mathrm{N}$ ratio was calculated by TOC and TN (TOC/TN ratio). ${ }^{13} \mathrm{C}$ was determined by GC-IRMS. $0.5 \mathrm{~mol} / \mathrm{L} \mathrm{HCl}$ was added to the sediment samples to remove inorganic carbonate, and the samples were washed with as $\delta^{13} \mathrm{C}$ value in \%o relative to Vienna Pee Dee Belemnite (VPDB) according to eq. (1) [33]:

$$
\delta^{13} C=\frac{R_{\text {sample }}-R_{\text {reference }}}{R_{\text {reference }}} \times 1000
$$


where $R_{\text {sample }}$ and $R_{\text {reference }}$ are isotope ratios of the elements of concern in the target compound and the international reference standard (e.g., VPDB for the carbon isotope), respectively.

It has been reported that the organic carbon in salt marsh surface sediments mainly comes from plants suspended particulate matter and benthic microalgae [10, 16, 34-36].

It's well known that plants can convert atmospheric $\mathrm{CO}_{2}$ into organic carbon through photosynthesis and store it in sediments, which are generally considered as one of the important sources of organic carbon in sediments. Suspended particulate matter is an important source of organic carbon in salt marshes with rapid deposition. The organic primary productivity of benthic microalgae in the Yangtze Estuary accounts for about $16.53 \%$ [37], and the ${ }^{13} \mathrm{C}$ field labeling method indicates that benthic microalgae is a potentially important source of organic carbon in sediments [38].Therefore, it is assumed that the main sources of sediment in Dongtan salt marsh are salt marsh vegetation (the vegetation of the sampling site consists of SA, PA and SM) suspended sediment and benthic microalgae. Based on the $\delta^{13} \mathrm{C}$ linear mixing model, the contribution rate of organic carbon sources in sediments can be calculated by the following eq. (2-4) [39]:

$$
[T N / T O C]_{\text {sed }}=f_{\text {plant }}[\text { TN } / \text { TOC }]_{\text {plant }}+f_{S P M}[T N / T O C]_{S P M}+f_{M P B}[T N / T O C]_{M P B}
$$

$$
\delta^{13} C_{\text {sed }}=f_{\text {plant }} \times \delta^{13} C_{\text {plant }}+f_{S P M} \times \delta^{13} C_{S P M}+f_{M P B} \times \delta^{13} C_{M P B}
$$

$$
f_{\text {plant }}+f_{S P M}+f_{M P B}=1
$$

Where $f_{\text {plant }}(\%), f_{S P M}(\%)$ and $f_{M P B}(\%)$ are the contribution rates of vegetation, 
171 the sampling sites, respectively. $\delta^{13} C_{\text {sed }}(\%)$ is the $\delta^{13} \mathrm{C}$ value of the sediment sample.

$172 \delta^{13} C_{\text {plant }}(\%), \delta^{13} C_{S P M}(\%)$ and $\delta^{13} C_{M P B}(\%)$ were calculated for the $\delta^{13} \mathrm{C}$ values of

173 vegetation, suspended particulate matter and microphytobenthos at the sampling sites,

174 respectively.

175 Statistical analysis

176 The mean and standard deviation values were calculated from the triplicate

177 measurements for each sample. Linear regression analysis and Pearson correlation were

178 used to identify relationships between TOC, TN, and plant biomass. Test results were

179 reported with a confidence level of $95 \%$ ( $P$-values of 0.05$)$. All statistical analyses were

180 performed using R statistical software.

\section{Results and discussion}

\section{Characteristics of TOC, TN, C/N and $\delta^{13} \mathrm{C}$ in sediments}

The average contents of TOC and TN in the surface sediments of wetland were $1.39 \% \pm 0.34 \%$ and $0.091 \% \pm 0.024 \%$, respectively (Fig. $2 \mathrm{a}$ and $\mathrm{b}$ ). There was a significant positive correlation between TOC and $\mathrm{TN}\left(r^{2}>0.95\right.$,). The $\mathrm{C} / \mathrm{N}$ ratio and $\delta^{13} \mathrm{C}$ in sediments ranged from 14.66 to 16.55 and -25.23 to $-22.45 \%$, with an average value of 15.44 and $-24.17 \%$, respectively (Fig. $2 \mathrm{c}$ and d). The contents of TOC and TN in sediments under different vegetation cover are shown in Fig. 2, and the average values of both are following in order $\mathrm{SA}>\mathrm{PA}>\mathrm{SM}$. As shown in Fig. 2, the content of TOC in SA is the highest with a mean value of $1.76 \% \pm 0.38 \%$. The content of TOC in 
the sediment under the SA is mediate (average value is $1.45 \%$ ). The TN in sediments was similar to that of TOC (Fig. 2b). The content of TN in SA, PA, and SM is $0.120 \%$, $0.096 \%$, and $0.058 \%$, respectively. These results indicate that the distribution of sediment TOC and TN reserves is greatly influenced by vegetation cover type and photosynthesis $[2,43]$. Plants can directly affect the carbon cycle of wetland through photosynthesis, carbon sequestration and carbon distribution [23]. The soil carbon content of SA is much higher than that of SM, which may be due to the SA is C4 plant.

Compared with native $\mathrm{C} 3$ plants, $\mathrm{SA}$ is a $\mathrm{C} 4$ plant with a higher photosynthetic efficiency, higher net primary productivity, and aboveground and underground biomass up to 5 times and 3 times of that of hyacinth community, which is consistent with the other research results $[23,40]$. In addition, the high net primary productivity of vegetation, litter yield and decomposition process are of great significance to the formation of soil carbon pool [23, 41-44]. During the plant growth, 10 to 40 percent of photosynthetic products enter soil and sediment through root secretion, while most of the rest enter the carbon sink of soil sediments in the form of litters $[45,46]$. 


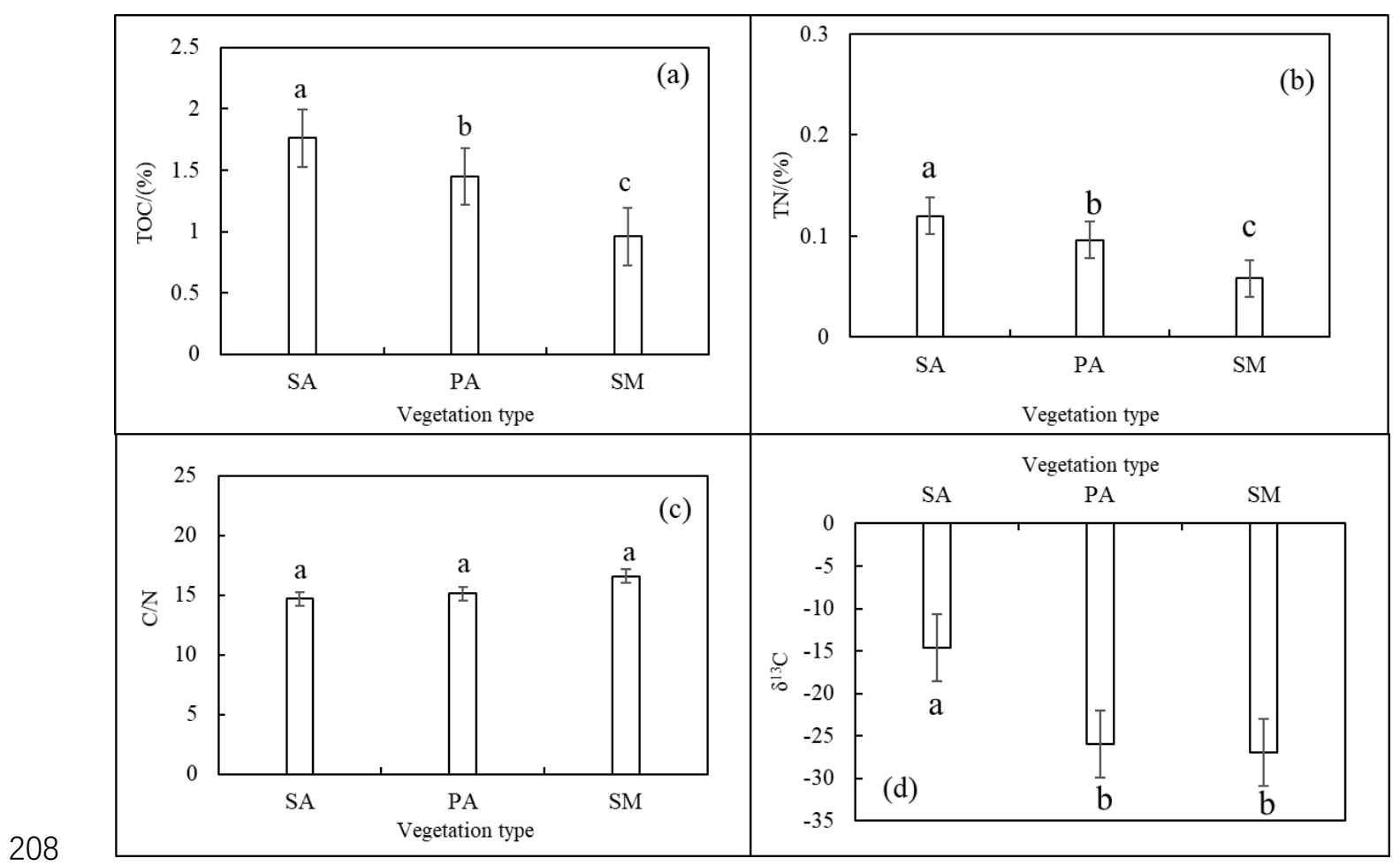

Fig. 2. Sedimentary physical properties and TOC, TN, C/N and $\delta^{13} \mathrm{C}$ of different vegetation zones.

Notes: SA presents Spartina alterniflora, PA presents Phragmites australis, SM presents Scirpus

mariqueter, the same as follows.

A large proportion of plant biomass (both above and below ground) inputs organic

carbon into the soil in the form of litters, and an increase in organic carbon ultimately

leads to an increase in soil carbon accumulation [47, 48], resulting in different

distribution characteristics of soil carbon stocks [23]. From Fig. 3, we found that the vegetation biomass were also in order SA $\left(1.91 \mathrm{~kg} / \mathrm{m}^{2}\right)>\mathrm{PA}\left(1.67 \mathrm{~kg} / \mathrm{m}^{2}\right)>\mathrm{SM}(1.33$

$217 \mathrm{~kg} / \mathrm{m}^{2}$ ), which is similar to the other results [2]. As the pioneer species of the salt marsh 218 vegetation in the Yangtze estuary, SM has low productivity and only $1 / 4$ of the biomass per unit area of the community of SA and PA, resulting the $\mathrm{C}$ and $\mathrm{N}$ reserve are relatively low. Furthermore, it has been reported that the invasion of the plant increased the organic carbon content of the soil $[49,50]$. These results indicated that the difference 
of plant community productivity is the main factor influencing soil carbon storage, and

223 the increase of soil carbon storage is not only closely related to the physical and 224 chemical properties of soils, but also depends on the storage and fixation capacity of 225 different plant communities for carbon [23]. There was a significant linear relationship 226 between the sediment carbon content and the underground biomass of the three salt marsh plant communities. With the increase of the biomass of the salt marsh plant communities, the TOC of the sediments increased, which may be related to the plant root growth, rhizosphere microbial activity and enzyme activity [2].

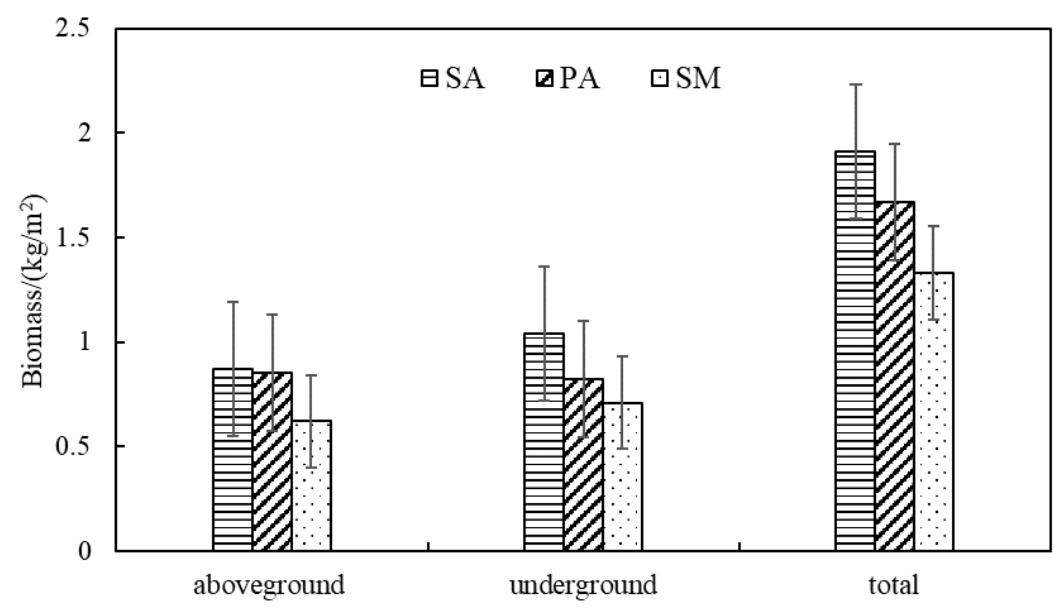

Fig. 3. The biomass of aboveground and underground biomass in different saltmarsh plant types.

\section{Spatial distribution characteristics of organic carbon contribution rate in} sediments

The contribution rate of organic carbon from different sources in the surface sediments of wetland was calculated by the three end-member mixing model (Fig. 4). The average contribution rate $\left(f_{\mathrm{SPM}}\right)$ of all samples in the study area was $44.44 \% \pm$ 
$20.89 \%$, followed by the contribution rate of vegetation $\left(f_{\text {plant }}\right)(34.50 \% \pm 25.23 \%)$ and contribution rate $\left(f_{\mathrm{MPB}}\right)$ of benthic microalgae $(23.06 \% \pm 4.62 \%)$. The $f_{\mathrm{plant}}$ of organic carbon in sediments under different vegetation belts showed significant differences. As shown in Fig. 4, the organic carbon $f_{\text {plant }}$ of the sediments in the SA was $5.81 \%$, which was significantly lower than that in the native C3 vegetation PA (53.27\%) and SM (44.43\%) $(P<0.05)$. The average organic carbon $f_{\text {SPM }}$ of the sediments in the $S A$ zone was $66.42 \%$, which was approximately twice as high as that of PA $(28.20 \%)$ and SM (32.69\%) $(P<0.05)$. In addition, we estimated the absolute contribution of sediment organic carbon from different vegetation types (Fig. 5), and the results showed that the absolute contribution of the vegetation to the TOC of sediments in the SA, PA, and SM zones is $0.10 \%, 0.77 \%$, and $0.42 \%$, respectively, indicating that PA belt was significantly higher than the other plant belts. However, the absolute contribution rate of suspended particulate showed opposite characteristics. The absolute contribution $\left(\mathrm{TOC} * f_{\mathrm{SPM}}\right)$ of suspended particulate matter in the SA belt to the organic carbon of sediments is the highest with a mean value of $1.16 \%$, followed by PA belt $(0.40 \%)$ and MA belt (0.31\%). Generally, the absolute contribution of microphytobenthos to organic carbon were lower. 
SA

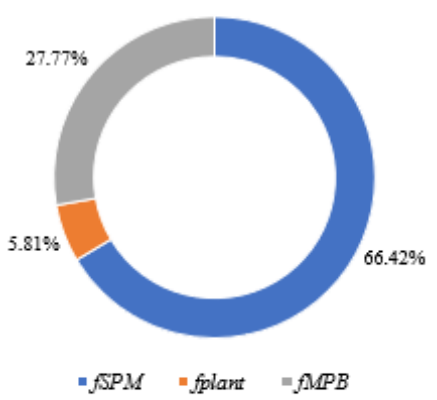

PA

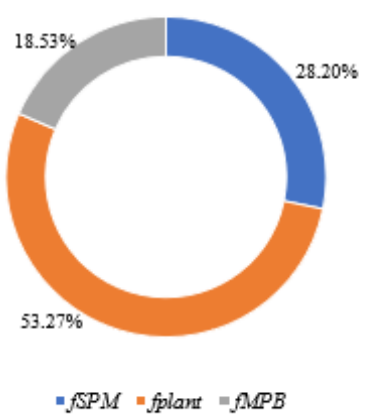

SM

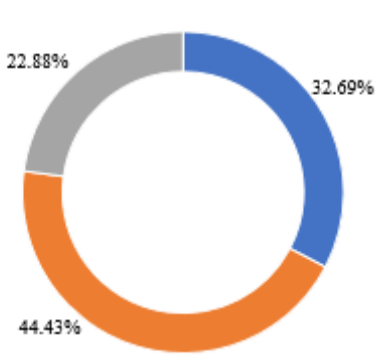

$-f S P M=f p l a n t=f M P B$ vegetation belts.

\section{sediments}

Fig. 4. Contribution of organic carbon from various sources of sediments in different vegetation belts. Notes: $f_{\text {plant }}, f_{\mathrm{MPB}}$ and $f_{\mathrm{SPM}}$ represent the relative fraction of vegetation, suspended particulate matter and microphytobenthos of these organic carbon sources. The same as below.

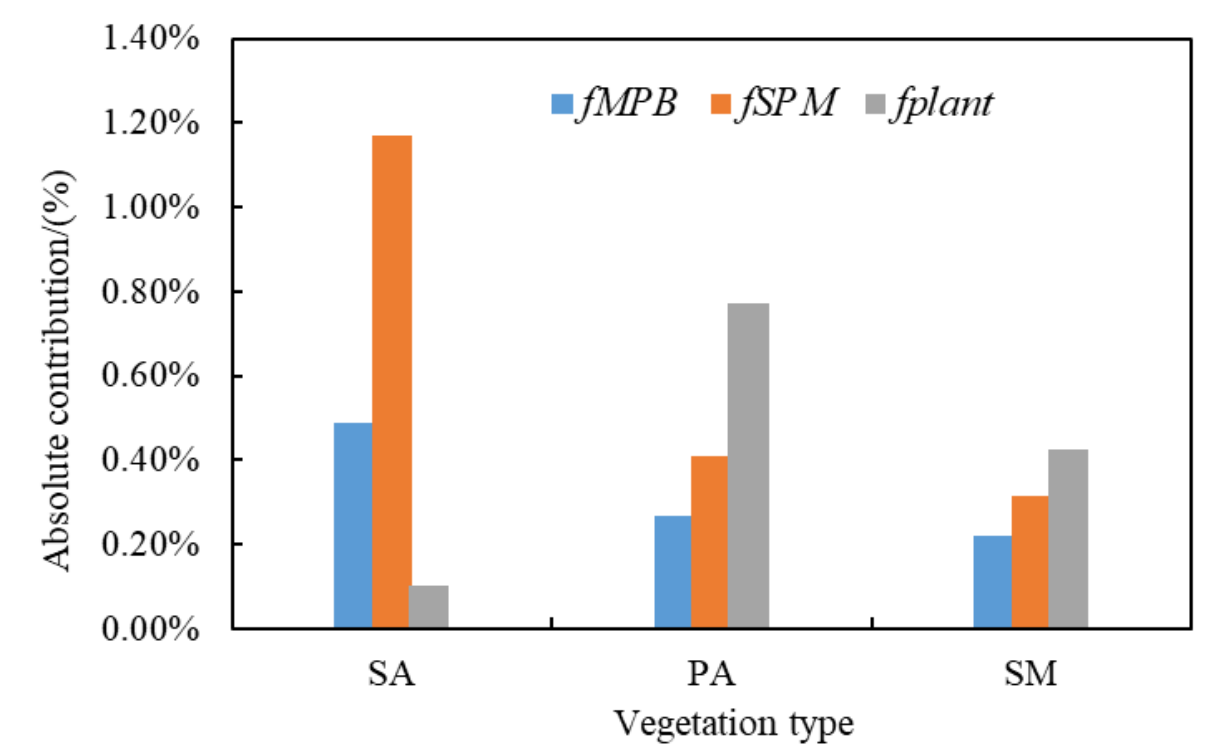

Fig. 5. Absolute contribution of organic carbon from various sources of sediments in different Source composition characteristics and influencing factors of organic carbon in

Estuarine salt marshes are subject to seaborne interactions, which determines the 
complexity of organic carbon sources in estuarine salt marshes sediments [51]. Many

studies have reported the use of $\mathrm{C} / \mathrm{N}$ ratio and stable isotope composition to analyze and explore the source of organic carbon in wetland sediments [52-54]. This study comprehensively analyzed the source of organic carbon in surface sediments based on the elemental and stable isotope composition characteristics of sediment samples, suspended particulate matter, vegetation and benthic microalgae in the study area. In general, the $\mathrm{C} / \mathrm{N}$ of marine organic carbon is $6 \sim 9$, and that of terrestrial organic carbon is $\mathrm{C} / \mathrm{N}>12[55,56]$. In this study, the $\mathrm{C} / \mathrm{N}$ ratios were all greater than 9 , indicating that the organic carbon in the sediments might be the result of mixed input of terrestrial organic carbon and Marine organic carbon. $\delta^{13} \mathrm{C}$ tracer results showed that the organic carbon in wetland surface sediments was mainly from suspended particulate matter and salt marsh plants, with the combined average contribution rate of TOC to sediments reaching $76.94 \%$, indicating that suspended particles and native plants were the main sources of organic carbon in sediments, which is consistent with the other researches $[10,51]$

Vegetation is an important biological factor for ecological succession and another important factor for controlling the composition of the salt marsh sediment source. Due to the differences in biological characteristics, the amount of organic matter input to the sediment by different vegetation varies greatly $[2,10,57]$. The differences in plant material components such as lignin content will affect the rate of plant litter degradation to other environmental media [58], and these factors interact with the time of plant community formation, and together affect the plant's contribution to sediment organic 
carbon [10]. The process of vegetation and deposition in coastal estuarine wetlands is complex [59]. The deposition process is usually accompanied by the burial of litters, thus promoting the accumulation of carbon in the soil and sediments [24]. The dominant vegetation in the study area was mainly composed of native C3 plants (PA and SM) and exotic $\mathrm{C} 4$ plants (SA). It has been shown that the invasion of SA can increase the TOC content of sediments (especially the active organic carbon component) in a short period of time [60]. However, the content of $\mathrm{N}$ in litters was higher, the content of cellulose and lignin was lower, and its decomposability was higher than that of native plants PA and SM [2]. In addition, in terms of the grain size of sediments, the higher the elevation of the beach, the finer the matter, and vice versa [22]. Therefore, the changes of the corresponding abiotic components (such as elevation, sediment size, nutrient and salinity, etc.) and environmental factors (Season, temperature, and microbial diversity etc.) also play an important role in wetland soil carbon storage, which needs further study.

\section{Conclusions}

This study investigated the distribution characteristics of carbon content in sediments in different vegetation zones of typical wetlands in the Yangtze Estuary and the sources of organic carbon. The mean value of TOC and TN concentrations in the surface sediments of wetland were $1.39 \pm 0.34 \%$ and $0.091 \pm 0.024 \%$, respectively. The TOC of the sediment in the three saltmarsh plant communities was in the order of SA $(1.76 \pm 0.38 \%)>\mathrm{PA}(1.45 \pm 0.37 \%)>\mathrm{SM}(0.96 \pm 0.44 \%)$. The mean sediment $\delta^{13} \mathrm{C}$ value was $-24.17 \pm 1.51 \%$, and all the $\mathrm{C} / \mathrm{N}$ ratios were both greater than 9 . The organic 
carbon in sediments of wetland in Yangtze Estuary are the result of mixed input of terrestrial organic carbon and marine organic carbon. Organic carbon in sediments was mainly derived from suspended particles and vegetations. Vegetation plays an important role in the carbon storage of wetland sediments. The primary productivity of salt marsh vegetation is the main factor influencing the spatial distribution of soil carbon storage in estuarine wetland. Significant differences in TOC and TN in sediments under different vegetation, were represented as $\mathrm{SA}>\mathrm{PA}>\mathrm{SM}$. The source of organic carbon in wetland sediments was qualitatively analyzed by $\mathrm{C} / \mathrm{N}$ ratio and three-terminal model. The values of $\mathrm{C} / \mathrm{N}$ were beyond 9 , indicating that the organic carbon of sediments may be mixed input of terrestrial and marine organic carbon. The three end-member mixing equations showed that the organic carbon in the sediments in the study area mainly came from the suspended particles brought by rivers and the terrestrial vegetation cover in salt marshes, while the contribution of benthic microalgae was small. This study provides a preliminary knowledge of the distribution and source of organic carbon in wetland sediments, providing theoretical support for a better understanding of the circulation of carbon in sediments environment.

\section{Abbreviations}

TOC: total organic carbon; $\mathrm{TN}$ : total nitrogen; $\delta^{13} \mathrm{C}$ : carbon stable isotope; $\mathrm{C} / \mathrm{N}$ : the ratio of carbon/nitrogen; TN/TOC: the ratio of total nitrogen/total organic carbon; TOC/TN: the ratio of total organic carbon/total nitrogen; N: nitrogen; C: carbon; SA: 
microphytobenthos; SPM: Suspended particulate matter.

\section{Ethics approval and consent to participate}

337 Not applicable.

\section{Consent for publication}

339 Not applicable.

\section{Availability of data and materials}

341 The data sets supporting the conclusions of this article are included within the article.

342 Competing interests

343 The authors declare that they have no competing interests.

\section{$344 \quad$ Funding}

345 This work was supported by the National Key R\&D Program of China 346 (2018YFC1803100) and National Natural Science Foundation of China (No. 347 21377098).

\section{Authors' contributions}

Haiyan Yu, Weiwei Li, Changxu Han, Han Fang, Xingquan Shu, and Yongfeng Liu performed the experiments. Haiyan Yu wrote the manuscript. Limin Ma and Yuwei Pan contributed to the manuscript correction. All authors read and approved the final manuscript.

\section{Acknowledgements}

354 The valuable comments of Professor Limin Ma are acknowledged.

\section{References}

1. Dussaillant, A.; Galdames, P.; Sun, C. L. (2009) Water level fluctuations in a coastal lagoon: El Yali Ramsar wetland, Chile. Desalination, 246 (1-3), 202-214.

2. Zhang, T. Y., Ge, Z. M., Zhang, L. Q., Chen, H.P., Yan, G. (2015) Influence of saltmarsh vegetation and sedimentation on the distribution of soil carbon and nitrogen in the Chongming Dongtan wetlands. Acta Scientiae Circumstantiae, 35(3), 836-843

3. Huang, H.M., Zhang, L.Q., Yuan, L. (2007) The spatio-temporal dynamics of salt marsh vegetation for Chongming Dongtan National Nature Reserve, Shanghai. Acta Ecologica Sinica, 27 (10),4166-4172.

4. Liu, M., Hou, L.J., Xu, S.Y., Ou, D.N., Jiang, H.Y., Yu, J., Gardner Wayne, S. (2004.) Carbon 
and Nitrogen Stable Isotopes as Tracers to Source Organic Matter in the Yangtze Estuary. Acta Geographica Sinica, 59(6), 918-926.

5. Ouyang, X.; Lee, S. Y. (2014) Updated estimates of carbon accumulation rates in coastal marsh sediments. Biogeosciences, 11(18), 5057-5071.

6. Carbon sink for a century.

7. Chmura, G. L.; Anisfeld, S. C.; Cahoon, D. R.; Lynch, J. C., Global carbon sequestration in tidal, saline wetland soils. Global Biogeochemical Cycles 2003, 17, (4), n/a-n/a.

8. Alongi, D. M. (2014) Carbon cycling and storage in mangrove forests. Ann Rev Mar Sci, 6, 195-219.

9. McLeod, E., Chmura, G. L., Bouillon, S., Salm, R., Björk, M., Duarte, C. M., Lovelock, C. E., Schlesinger, W.H., Silliman, B. R. (2011) A blueprint for blue carbon: toward an improved understanding of the role of vegetated coastal habitats in sequestering $\mathrm{CO}_{2}$. Frontiers in Ecology and the Environment, 9 (10), 552-560.

10. Dun, Y., Wang, C., Yao, D.J., Huang, M.H., Xu, J.X. (2019) Spatial Distribution Characteristics and Source Tracing of Organic Carbon in Surface Sediments of Salt Marsh in Dongtan of Chongming. Resources and Environment in the Yangtze Basin, 28(1), 157-165.

11. Jordan, S.J., Stoffer, J., Nestlerode, J.A. (2011) Wetlands as Sinks for Reactive Nitrogen at Continental and Global Scales: A Meta-Analysis. Ecosystems, 14(1), 144-155.

12. Mao, Z.G., Wang, G.., Liu, J. E., Ren, L.J. (2009) Influence of salt marsh vegetation on spatial distribution of soil carbon and nitrogen in Yancheng coastal wetland. The journal of applied ecology, 20(2), 293-7.

13. Mitsch, W. J., Bernal, B., Nahlik, A. M., Mander, Ü., Zhang, L., Anderson, C. J., Jørgensen, S. E., Brix, H. (2012) Wetlands, carbon, and climate change. Landscape Ecology, 28 (4), 583597.

14. Ge, C.D., Wang, Y., Pedersen, T.F., Slaymaker, O. (2007) Variability of organic carbon isotopes, nitrogen isotopes, and carbon/nitrogen in Wanquan river estuary, eastern Hainan Island China and its environmental implications. Quaternary Sciences, 27(5), 845-852.

15. Wu, Y., Zhang, J., Zhang, Z.F., Ren, J.L., Cao, J.P. (2002) Seasonal variability of stable carbon and nitrogen isotope of suspended particulate matter in the Changjiang River. Oceanolgia et Limnologia Sinica, 33(5): 546-552.

16. Chao, H.J., Gao, J.H., Jia, J.J., Zhang, C.C., Guo, J.L., Xue, C.F. (2017) Change of organic matter sources in surface sediments over Changjiang estuary and its adjacent waters. Marine Environmental Science, 36(2), 237-242.

17. Wang, Q. (2011) The history, present situation and forecast of the mutual invasion of east beach in chongming, Shanghai. Chinese Journal of Mechanical Engineering,20(6),690-696.

18. Gao, S.; Wang, Y. P. (2008) Changes in material fluxes from the Changjiang River and their implications on the adjoining continental shelf ecosystem. Continental Shelf Research, 28, (12), 1490-1500.

19. Gao, Y., Zhao, B. (2006) The Effect of Reclamation on Mud Flat Development in Chongming Island, Shanghai. Chinese Agricultural Science Bulletin,22(8),475-479.

20. Chen, Z.Y., Li, B., Chen, J.K. (2004) Ecological consequences and management of Spartina spp. invasions in coastal ecosystems. Chinese Biodiversity, 12(2), 280-289.

21. Li, H. (2006) Distribution of an exotic plant Spartina alterniflora in Shanghai. Biodiversity Science, 14, (2), 114. 
22. Mei, X.Y., Zhang, X.F. (2007) Carbon storage and carbon fixation during the succession of natural vegetation in wetland ecosystem on east beach of Chongming Island. The journal of applied ecology, 18(4), 933-6.

23. Yan, G., Ge, Z.M., Zhang, L.Q. (2014) Distribution of soil carbon storage in different saltmarsh plant communities in Chongming Dongtan wetland. The journal of applied ecology, 25(1), 8591.

24. Anderson, C.J., Mitsch, W.J. (2006) Sediment, carbon, and nutrient accumulation at two 10year-old created riverine marshes. Wetlands, 26(3), 779-792.

25. Zhou, J.; Wu, Y.; Kang, Q.; Zhang, J. (2007) Spatial variations of carbon, nitrogen, phosphorous and sulfur in the salt marsh sediments of the Yangtze Estuary in China. Estuarine, Coastal and Shelf Science, 71(1-2), 47-59.

26. Wu, Y., Zhang, J., Liu, S. M., Zhang, Z. F., Yao, Q. Z., Hong, G. H., Cooper, L. (2007) Sources and distribution of carbon within the Yangtze River system. Estuarine, Coastal and Shelf Science, 71, (1-2), 13-25.

27. Graham, M. C., Eaves, M. A., Farmer, J. G., Dobson, J., Fallick, A. E. (2001) A Study of Carbon and Nitrogen Stable Isotope and Elemental Ratios as Potential Indicators of Source and Fate of Organic Matter in Sediments of the Forth Estuary, Scotland. Estuarine, Coastal and Shelf Science, 52, (3), 375-380.

28. Ge, Z.M., Zhou, X., Wang, K.Y., Seppo Kellom(a)ki; Gong, J.N. (2010) Research methodology on carbon pool dynamics in the typical wetland of Yangtze River estuary. Acta Ecologica Sinica, 30(4), 1097-1108.

29. Jiang, J.Y., Huang, X., Li, X.Z., Yan, Z.Z., Li, X.Z., Ding, W.H. (2015) Soil organic carbon storage in Tidal Wetland and its relationships with soil physico-chemical factors: A case study of Dongtan of Chongming, Shanghai. Journal of Ecology and Rural Environment, 31(4), 540547.

30. Dan, W., Rong, Z., Jun, X., Hai, Q., G. U. O., Zhao, B. (2015) Contribution of invasive species Spartina alterniflora to soil organic carbon pool in coastal wetland: Stable isotope approach. Chinese Journal of Plant Ecology, 39, (10), 941-949.

31. Bao, S.D., 2000. Soil Agrochemical Analysis. China Agriculture Press, Beijing.

32. Mazumder, D.; Iles, J.; Kelleway, J.; Kobayashi, T.; Knowles, L.; Saintilan, N.; Hollins, S. (2010) Effect of acidification on elemental and isotopic compositions of sediment organic matter and macro-invertebrate muscle tissues in food web research. Rapid Commun Mass Spectrom, 24, (20), 2938-42.

33. Coplen, T. B. (2010) Guidelines and recommended terms for expression of stable-isotope-ratio and gas-ratio measurement results. Rapid Communications in Mass Spectrometry 2011, 25, (17), 2538-2560.

34. Gontharet, S.; Artigas, L. F.; Mathieu, O.; Leveque, J.; Milloux, M. J.; Caillaud, J.; Philippe, S.; Lesourd, S.; Gardel, A. (2015) Effect of emersion/immersion cycles on the elemental and isotopic compositions of the organic matter from surface sediments of an intertidal mud bank (French Guiana): a preliminary study. Rapid Commun Mass Spectrom, 29, (22), 2147-57.

35. Kendall, C.; Silva, S. R.; Kelly, V. J. (2001) Carbon and nitrogen isotopic compositions of particulate organic matter in four large river systems across the United States. Hydrological Processes, 15, (7), 1301-1346.

36. Onstad, G.D., Canfield, D.E., Quay, P.D., Hedges, J.I. (2000) Sources of particulate organic 
matter in rivers from the continental USA: Lignin phenol and stable carbon isotope compositions. Geography and cosmology cata. 64(20), 3539-3546.

37. Shang, X., Guan, W.B., Zhang, J. (2009) Distribution characteristics and contribution to total primary production of microphotobenthos in the salt marshes of the Changjiang Estuary. Acta Oceanologica Sinica, 31(5),40-47.

38. Oakes, J. M., Eyre, B. D. (2014)Transformation and fate of microphytobenthos carbon in subtropical, intertidal sediments: potential for long - term carbon retention revealed by $13 \mathrm{C}$ - labeling. Biogeosciences Discussions,10(12), 19773-19809.

39. Gontharet, S., Mathieu, O., Lévêque, J., Milloux, M. J., Lesourd, S., Philippe, S., Caillaud, J., Gardel, A., Sarrazin, M., Proisy, C. (2014) Distribution and sources of bulk organic matter (OM) on a tropical intertidal mud bank in French Guiana from elemental and isotopic proxies. Chemical Geology, 376, 1-10.

40. Zhang, L.H., Zeng, C.S., Tong, C. (2008) Study on Biomass Dynamics of Phragmites australis and Spartina alterniflora in the Wetlands of Minjiang River Estuary. Journal of Subtropical Resources and Environment,3(2), 25-33.

41. Cao, L., Song, J.M., Li, X.G., Yuan, H.M., Li, N., Duan, L.Q. (2013) Deposition and burial of organic carbon in coastal salt marsh: research progress. The journal of applied ecology, 24(7), 2040-8.

42. Kirwan, M. L.; Mudd, S. M. (2012) Response of salt-marsh carbon accumulation to climate change. Nature, 489, (7417), 550-3.

43. Wang, P., Sheng, L.X., Yan, H., Zhou, D.W., Song, Y.T. (2010) Plant functional traits influence soil carbon sequestration in wetland ecosystem. Acta Ecologica Sinica, 30(24), 6990-7000.

44. Duan, X.N., Wang, X.K., Lu, F., Ouyang, Z.Y. (2008) Carbon sequestration and its potential by wetland ecosystems in China. Acta Ecologica Sinica, 28(2), 463-469.

45. Kaštovská, E.; Šantrůčková, H. (2007) Fate and dynamics of recently fixed C in pasture plantsoil system under field conditions. Plant and Soil, 300, (1-2), 61-69.

46. Yu, J.B., Wang, Y.L., Dong, H.F., Wang, X.H., Li, Y.Z., Zhou, D., Gao, Y.J. (2013) Estimation of Soil Organic Carbon Storage in Coastal Wetlands of Modern Yellow River Delta based on Landscape Pattern. Wetland Science, 11(1), 1-6.

47. Rovira, P., Vallejo, V.R. (2002) Labile and recalcitrant pools of carbon and nitrogen in organic matter decomposing at different depths in soil: An acid hydrolysis approach. Geoderma, 107 (1-2), 109-141.

48. Sistla, S. A., Moore, J. C., Simpson, R. T., Gough, L., Shaver, G. R., Schimel, J. P. (2013) Long-term warming restructures Arctic tundra without changing net soil carbon storage. Nature, 497, (7451), 615-8.

49. Gao, J.H., Yang, G.S., Ou, W.X. (2007) The influence after introduction of Spartina alterniflora on the distribution of TOC, TN and TP in the national Yancheng rare birds nature reserve, Jiangsu Province, China. Geographical Research, 26(4), 799-808.

50. Zhang, Y.Y., Zhang, F.C., Zhou, X.D., Xie, X.J, Wang, X.W., Li, Q., Lei, J. (2011) Effects of plant invasion along a Spartina alterniflora chronosequence on organic carbon dynamics in coastal wetland in north Jiangsu. China Environmental Science, 31(2), 271-276.

51. Chen, Q.Q., Zhou, J.Z., Meng, Y.; Hu, K.L., Gu, J.H. (2007) Organic carbon accumulation effect of salt marsh flat surface evolution in changjiang estuary. Progress in Natural Science, $17(5), 614-623$. 
52. Kenney, W. F.; Brenner, M.; Curtis, J. H.; Schelske, C. L. (2010) Identifying sources of organic matter in sediments of shallow lakes using multiple geochemical variables. Journal of Paleolimnology, 44, (4), 1039-1052.

53. Moens, T., Luyten, C., Middelburg, J.J., Herman, P.M.J., Vincx, M. (2002) Tracing organic matter sources of estuarine tidal flat nematodes with stable carbon isotopes. Marine Ecology Progress Series, 234, 127-137

54. Gao, L.M., Yao, P., Wang, J.P., Zhao, B. (2016) Distribution and sources of organic carbon in surface sediments from the Bohai Sea. Acta Oceanologica Sinica, 38(6), 8-20.

55. Cifuentes, L.A., Coffin, R.B., Solorzano, L., Cardenas, W., Espinoza, J., Twilley, R.R. (1996) Isotopic and Elemental Variations of Carbon and Nitrogen in a Mangrove Estuary. Estuarine Coastal and shelf science,43(6), 781-800.

56. Prahl, F.G., Bennett, J.T., Carpenter, R. (1980) The early diagenesis of aliphatic hydrocarbons and organic matter in sedimentary particulates from Dabob Bay, Washington. Geochimica et cosmochimica acta, 44(12),1967-1976.

57. Bertness, M.D., Leonard, G.H. (1997) The role of positive interactions in communities_Lessons from intertidal habitats. Ecology,78(7),1976-1989.

58. Duan, H., Wang, L., Zhang, Y., Fu, X., Tsang, Y., Wu, J., Le, Y. (2018) Variable decomposition of two plant litters and their effects on the carbon sequestration ability of wetland soil in the Yangtze River estuary. Geoderma, 319, 230-238.

59. Zhu, Z.; Zhang, L.; Wang, N.; Schwarz, C.; Ysebaert, T. (2012) Interactions between the range expansion of saltmarsh vegetation and hydrodynamic regimes in the Yangtze Estuary, China. Estuarine. Coastal and Shelf Science, 96, 273-279.

60. Yang, W., An, S., Zhao, H., Fang, S., Xia, L., Xiao, Y., Qiao, Y., Cheng, X. (2015) Labile and Recalcitrant Soil Carbon and Nitrogen Pools in Tidal Salt Marshes of the Eastern Chinese Coast as Affected by Short-Term C4PlantSpartina alterniflora Invasion. Clean-Soil, Air, Water, 43(6), 872-880. 